\title{
EVALUATING THE RELATIONSHIP BETWEEN INVESTMENT IN INNOVATION AND THE VOLUME OF SOLD INNOVATIVE PRODUCTS IN THE INDUSTRY OF UKRAINE
}

\author{
Larysa Kovchuha
}

\begin{abstract}
Applying the correlation and regression analysis, the study of the relationship between the volume and structure of innovation costs and the volume of sold innovative products (SIP) in industry was carried out on the example of Ukraine. The time lag of the costsof-sales impact was also considered. It was hypothesized that the total volume of sold innovative products and their structure (the share of new products for the market, the share of products sold abroad) depend on different types of investment in innovation. The correlation and regression analysis showed that the components of investment in innovation influenced differently the volume and structure of SIP, which confirmed the hypothesis. The total amount of SIP largely depends on the level of costs to purchase machinery, equipment and software, as well as costs related to the component "Other". Positive dynamics of sold innovative products that are new to the market, as well as the products sold abroad, is largely determined by the volume of expenditures on external scientific research. Thus, by influencing the structure of investment in innovation, a company can significantly increase the level of its competitiveness.
\end{abstract}

Keywords: innovations, costs of innovation activity, structure of innovation costs, industry, innovative products, level of competitiveness

JEL Classification: D920, O310

\section{Author:}

Larysa Kovchuha

Institute of Industrial Economics of the National Academy of Sciences of Ukraine,

2 Maria Kapnist Street, Kyiv, Ukraine, 03057

E-mail: larakovi@ukr.net

https://orcid.org/0000-0001-6448-0400

Citation: Kovchuha, L. (2020). Evaluating the Relationship between Investment in Innovation and the Volume of Sold Innovative Products in the Industry of Ukraine. Virtual Economics, 3(3), 67-79. https://doi.org/10.34021/ve.2020.03.03(4)

Received: December 27, 2019. Revised: March 24, 2020. Accepted: June 3, 2020.

(C) Author(s) 2020. Licensed under the Creative Commons License - Attribution 4.0 International (CC BY 4.0) 


\section{Introduction}

Investment in innovation is one of the important factors of enterprises' innovative development. Investment is a dominant factor in the stable development of the economy. Innovation and investment are two inextricably connected economic processes. Investments form financial resources needed to implement most innovations, especially technological ones. That is why most researchers consider investment and innovation processes as interdependent phenomena.

\section{Literature Review}

There is a considerable number of studies evaluating the relationship between innovation costs and company performance. For example, Morris (2018) empirically proved that innovatively active companies are much more productive in the manufacturing sector as well as in the sector of services. A positive impact of product innovations on the companies' efficiency in developing countries was revealed in the work by Ramadani et al. (2019). The results of this study showed that company performance is most positively influenced by such factors as personnel qualifications, modern technologies and cooperation with foreign companies. The econometric analysis, presented in the work by Ciocanel et al. (2015), was conducted to confirm the existence of a cause-and-effect relation between innovation and competitiveness on the example of then 28 countries of the European Union. The analysis of innovation impact on competitiveness has confirmed that an "innovation paradigm" is resilient to restoring the competitive advantages lost by the countries during the economic crisis.

However, a positive relationship between innovation and productivity is not always clear. The study presented by Haltiwanger et al. (2003) showed that the application of advanced technologies gave a larger work productivity increase in the United States than in Germany. In the work by Carvalho et al. (2016), the insignificant impact of innovations on the productivity of Brazilian enterprises was empirically proven. The Ukrainian scientists have found that in the industrial regions of Ukraine the factor of research and development and innovation does not play a meaningful role in forming a gross regional product (Soldak \& Shamileva, 2018). The analysis of the literature shows a significant interest of scientists in the problem of the relationship between innovation costs, company performance and competitiveness of the national economies. However, there is still no consensus among the economists on the benefits of innovation as a determinant of the productivity increase (Alymov et al., 2014; Amosha et al., 2019; Amosha et al., 2018; Boiko et al., 2019; Czyżewski et al., 2019; Dementyev \& Kwilinski, 2020; Dzwigol, 2020a; 2020b; Dzwigol et al., 2019a; 2019b; 2019c; 2020b; Dźwigoł \& Wolniak, 2018; Golovatyuk et al., 2018; Jamel et al., 2020; Furmaniak et al., 2018; 2019a; 2019b; Kuzior et al., 2019; Kuzior \& Kuzior, 2020; Kwilinski, 2019; Kwilinski \& Kuzior, 2020; Kwilinski et al., 2019a; 2019b; 2019c; 2019d; 2020a; 2020b; 2020c; 2020d; 2020e; Miśkiewicz, 2018; Miśkiewicz, \& Wolniak, 2020; Pająk et al., 2016; 2017; Savchenko et al., 2019; Tkachenko et al., 2019a; 2019b; 2019c; 2019d). The research results differ both in terms of types of innovation, and among countries. 
Unlike the majority of the existing works, this article has the objective to evaluate the relationship not only between innovation costs and their results, but also to identify the dependence of the volume of sold innovative products (SIP) and their share, which is new to the market, as well as the volumes of products sold outside Ukraine, on the various types of innovation costs.

\section{Methodology}

To achieve the objective set, the methods of analysis and synthesis, comparative analysis and correlation-regression analysis were applied. The application package "Statistika" software was used. The industry of Ukraine was chosen as the object for observation. The specificity of the statistical information available determined 2017 as the time framework of the analysis. The research hypothesis is formulated as follows: the total volume of SIP and its share, which is new for the market, as well as SIP volume outside Ukraine, depend on different types of investments in innovation. Therefore, the following tasks were set:

- to study the interdependence between the volume and structure of costs for innovation activities and the volume of sold innovative products, taking into account the time lag of the impact of costs on sales volumes;

- to research the relationship between the costs of innovation and the volume of sold innovative products that were new to the market;

- to study the relationship between innovation costs and the volume of sold innovative products in the overseas markets.

The relationship between SIP volumes and total volumes of investment, including innovation, is stochastic. First of all, this is due to the fact that sales volumes, in addition to costs, are influenced by other factors, including market conditions in domestic and foreign markets, the level of knowledge-intensive economic activities and others. Under such conditions, determining the relationship between costs and results of innovation and its quantitative measurement is based on the econometric modelling, in particular, correlation-regression dependencies.

Regression models are based on the following initial hypothesis: the innovation costs affect the change in the volume of SIP both directly "year after year", and with one- or two-year time lag. A general view of regression models will be as follows:

$$
Y x_{i, t}=F\left(x_{i, t}\right) ; \text { or } Y x_{i, t}=F\left(x_{i, t-1}\right) ; Y x_{i, t}=F\left(x_{i, t-2}\right)
$$

where $Y x_{i, t}$ is estimated sales of innovative products in the tyear;

$x_{i, t}$ are expenditures for the $t$ year;

$x_{i, t-1} ; x_{i, t-2}$ are the costs for $(\mathrm{t}-1)$ and $(\mathrm{t}-2)$ years respectively;

$i$ is the areas of innovation. 
Expenditures in those areas of innovation which are presented in statistical books are: $x_{1}$ is total expenditures on innovation; $x_{2}$ is costs of internal scientific research and development (R\&D); $x_{3}$ is costs of external scientific research and development; $x_{4}$ is the purchase of machinery, equipment and software; $x_{5}$ is acquisition of existing knowledge from other enterprises or organizations; $x_{6}$ is other types of costs. Regression models are built on the official statistics of Ukraine, presented in the State Statistics Service of Ukraine (2018, pp. 90, 103, 105).

The form of the regression model which most adequately corresponds to the developed dependences is chosen based on the combination of optimum approximation criteria : $\min \Sigma\left(Y-Y x_{i, t}\right)^{2}$, a criterion of the least-squares method, max F-criterion (Fisher-Snedecor), $\min E_{\text {rel }}$ (relative approximation error), and the regression model must be statistically significant by F-criterion $\left(F_{p}>F_{\alpha}\right)$. Under such conditions, the model parameters objectively reflect the dependence that was developed on the set of objects that act as observation points.

\section{Results and Discussion}

The 2017 identified pair dependences indicate that there was a fairly close relationship between the volume of SIP $\left(Y_{1}\right)$ and the total costs of innovation $\left(x_{1}\right)$ (See equations (2) and (3).

$$
\begin{gathered}
Y_{1} x_{1}=475,935-1,137 x_{1}+0,003 x_{1}{ }^{2} ; \\
D y_{1} x_{1}=0,697 ; F_{p}=11,5 ; F_{\alpha}\{\alpha=0,05 ; v 1=2 ; v 2=7\}=4,74 ; \\
Y_{1} x_{1}=5,87 x_{1}{ }^{0,802} ; \\
D y_{1} x_{1}=0,616 ; F_{p}=17,6 ; F_{\alpha}\{\alpha=0,05 ; v 1=2 ; v 2=8\}=5,32 ;
\end{gathered}
$$

The density link is approximately the same, taking into account the one-year time lag. This is shown in equations (4), (5), (6). The calculated coefficients of determination $\left(D y_{1} x_{1}\right)$ show that, on average, the change in the volume of sold innovative products by $60.0 \%-70.0 \%$ is due to the change in the total costs for innovation.

$$
\begin{gathered}
Y_{1} x_{1}=5,16+1,87 x_{1}-0,0001 x_{1}{ }^{2} ; D y_{1} x_{1}=0,703 ; F_{p}=11,84 \\
Y_{1} x_{1}=5,16+1,87 x_{1}-0,0001 x_{1}{ }^{2} ; D y_{1} x_{1}=0,703 ; F_{p}=11,84 \\
Y_{1} x_{1}=475,935-1,137 x_{1}+0,003 x_{1}{ }^{2} ; D y_{1} x_{1}=0,697 ; F_{p}=11,5 \\
Y_{1} x_{1}=40,0 x_{1}{ }^{0,553} ; D y_{1} x_{1}=0,533 ; F_{p}=12,54
\end{gathered}
$$


When analysing the impact of total costs in certain areas of innovation, it was determined that the greatest change in the volume of SIP entails the costs of purchasing machinery, equipment and software. The density link is about 0.93 (see equation (7). The most condensed link was formed when estimating the impact of costs on the volume of SIP in the same year (2017) (see equations (7) and (8). Therefore, we can conclude that the volume of sold innovative products depends on those investments in innovation that were made in the same period. The elasticity of change in equation ( 8 ) is 0.701 , that is, each $\%$ of costs in this area is accompanied by an increase in SIP by $0.701 \%$.

$$
\begin{gathered}
Y_{1} x_{4}=413,44-0,752 x_{4}+0,004 x_{4}{ }^{2} ; D y_{1} x_{4}=0,93 ; F_{p}=65,5 \\
Y_{1} x_{4}=413,44-0,752 x_{4}+0,004 x_{4}{ }^{2} ; D y_{1} x_{4}=0,93 ; F_{p}=65,5 \\
Y_{1} x_{4}=16,5 x_{4}{ }^{0,701} ; D y_{1} x_{4}=0,628 ; F_{p}=18,5
\end{gathered}
$$

The second most condensed factor $x_{6}$ includes the costs of other types of innovation (staff training, market adaptation of innovations, design development, etc.), which is proved by significant coefficients of determination ( 0.752 and 0.532$)$. The dependence of SIP on the factor $x_{6}$ was calculated taking into account the one-year time lag - equations (9), (10) and two-year time lag - equation (11).

$$
\begin{aligned}
& Y_{1} x_{6}=26,83-30,31 x_{6}-0,057 x_{6}{ }^{2} ; D y_{1} x_{6}=0,752 ; F_{p}=15,5 \\
& Y_{1} x_{6}=26,83-30,31 x_{6}-0,057 x_{6}{ }^{2} ; D y_{1} x_{6}=0,752 ; F_{p}=15,5 \\
& Y_{1} x_{6}=126,2 x_{6}{ }^{0,55} ; D y_{1} x_{6}=0,532 ; F_{p}=12,5 \\
& Y_{1} x_{6}=126,2 x_{6}{ }^{0,55} ; D y_{1} x_{6}=0,532 ; F_{p}=12,5 \\
& Y_{1} x_{6}=361,4 x_{6}{ }^{0,291} ; D y_{1} x_{6}=0,233 ; F_{p}=3,34 \\
& Y_{1} x_{6}=361,4 x_{6}{ }^{0,291} ; D y_{1} x_{6}=0,233 ; F_{p}=3,34
\end{aligned}
$$

The study showed a rather moderate link between the volume of SIP and the costs of external R\&D $\left(x_{3}\right)$ with a one-year lag. They cause the change in SIP by $30.2 \%$ - equation (12); with a two-year lag, the link was rather weak. It is determined that the costs of other areas of innovation (internal research $\left(x_{2}\right)$, and acquisition of other external knowledge $\left(x_{5}\right)$ have a very little effect on the SIP dynamics.

$$
\begin{aligned}
& Y_{1} x_{3}=1126,6-16,01 x_{3}+0,26 x_{3}{ }^{2} ; D y_{1} x_{3}=0,302 ; F_{p}=2,16 \\
& Y_{1} x_{3}=1126,6-16,01 x_{3}+0,26 x_{3}{ }^{2} ; D y_{1} x_{3}=0,302 ; F_{p}=2,16
\end{aligned}
$$

There have been identified multifactor regression models, which determine the impact of all types of costs on the total amount of SIP in the areas of innovation: a linear model in kind equations (13), (14): 


$$
\begin{gathered}
Y_{1} x_{i}=-149,61+2,641 x_{2}-29,607 x_{3}+0,001 x_{4}+149,1 x_{5}+21,76 x_{6} \\
Y_{1} x_{i}=-149,61+2,641 x_{2}-29,607 x_{3}+0,001 x_{4}+149,1 x_{5}+21,76 x_{6} \\
D y_{1} x_{i}=0,912 ; F_{p}=4,5 ; F_{\alpha}\{\alpha=0,05 ; v 1=5 ; v 2=7\}=3,97
\end{gathered}
$$

Power model:

$$
\begin{aligned}
& Y_{1} x_{i}=19,03 x_{2}{ }^{0,367} x_{3}{ }^{-0,251} x_{4}{ }^{0,282} x_{5}{ }^{0,128} x_{6}{ }^{0,346} \\
& Y_{1} x_{i}=19,03 x_{2}{ }^{0,367} x_{3}{ }^{-0,251} x_{4}{ }^{0,282} x_{5}{ }^{0,128} x_{6}{ }^{0,346}
\end{aligned}
$$

It is established that the set of factors of the multifactor regression model (13) causes the change in the volume of SIP in the set of industries by $91.2 \%$. All factors, except $x_{3}$, directly affect the change in the volume of SIP. Partial coefficients of elasticity of the power function (14) show probable influence of factors: $1 \%$ of the costs of internal research provides an increase in SIP by $0.367 \%$, an increase of $1 \%$ in other innovations increases the volumes of SIP by $0.346 \%$, an increase of $1 \%$ in machine costs provides the increase in SIP by $0.282 \%$.

A very important characteristic of the innovation effectiveness is the indicators of the volume of sold innovative products which were new to the market and which were sold outside Ukraine. The change in the volume of sold innovative products new to the market is only $30 \%$ due to the impact of the total costs of innovation (see equations (15), (16)). There is a direct dependence with a moderate density link.

$$
\begin{gathered}
Y_{4} x_{1}=-18,93-0,664 x_{1}-0,0001294 x_{1}^{2} ; D y_{4} x_{1}=0,308 ; F_{p}=2,22 \\
Y_{4} x_{1}=-18,93-0,664 x_{1}-0,0001294 x_{1}^{2} ; D y_{4} x_{1}=0,308 ; F_{p}=2,22 \\
Y_{4} x_{1}=e^{-1,112} x_{1}^{0,952} ; D y_{4} x_{1}=0,294 ; F_{p}=4,58 \\
Y_{4} x_{1}=e^{-1,112} x_{1}^{0,952} ; D y_{4} x_{1}=0,294 ; F_{p}=4,58
\end{gathered}
$$

The largest change in the volume of SIP which are new to the market is determined by the volume of costs for the purchase of machinery, equipment and software $\left(x_{4}\right)$ - equation (17). The theoretical coefficient of elasticity determined by equation (18) shows that each increase of percentage in costs in this area is accompanied by an increase in sales of innovative products new to the market by $79.5 \%$.

$$
\begin{aligned}
& Y_{4} x_{4}=-96,358+1,812 x_{4}-0,001 x_{4}{ }^{2} ; D y_{4} x_{4}=0,416 ; F_{p}=3,57 \\
& Y_{4} x_{4}=-96,358+1,812 x_{4}-0,001 x_{4}{ }^{2} ; D y_{4} x_{4}=0,416 ; F_{p}=3,57
\end{aligned}
$$




$$
\begin{aligned}
& Y_{4} x_{4}=e^{0,31} x_{4}^{0,795} ; D y_{4} x_{4}=0,274 ; F_{p}=4,15 \\
& Y_{4} x_{4}=e^{0,31} x_{4}{ }^{0,795} ; D y_{4} x_{4}=0,274 ; F_{p}=4,15
\end{aligned}
$$

Regarding the impact of costs with a one-year lag, all types of costs in the areas of innovation were taken into account. It was found that the strength of the impact of 2016 total costs on the volume of SIP new to the market almost coincides with the results of 2017. There is a direct impact with moderate density link: each percentage increase in costs is accompanied by an increase in sales volumes of the new to the market innovative products by $0.65 \%$ (19). When estimating the impact of costs on separate areas of innovation, the highest density link was formed with $x_{4}\left(D y_{4} x_{4}=0,3\right), x_{2}\left(D y_{4} x_{2}=0,286\right), x_{6}\left(D y_{4} x_{6}=0,216\right)$. There is a direct moderate dependence in these areas of costs. The growth of each factor is accompanied by an increase in the volume of new to the market SIP. Taken together, these three factors account for almost $50 \%$ of changes in sales of innovative products that are new to the market (20), and standardized ratios (21) show twice the impact of costs of domestic R\&D than other areas of costs.

$$
\begin{gathered}
Y_{4} x_{1}=e^{0,651} x_{1}^{0,65} ; D y_{4} x_{1}=0,285 ; F_{p}=4,38 \\
Y_{4} x_{1}=e^{0,651} x_{1}^{0,65} ; D y_{4} x_{1}=0,285 ; F_{p}=4,38 \\
t Y_{4} x_{1}=0,52 t x_{2}+0,283 t x_{4}+0,288 t x_{6} \\
t Y_{4} x_{1}=0,52 t x_{2}+0,283 t x_{4}+0,288 t x_{6} \\
Y_{6} x_{1}=e^{1,18} x_{1}^{0,672} ; D y_{6} x_{1}=0,243 ; F_{p}=3,2 \\
Y_{6} x_{1}=e^{1,18} x_{1}^{0,672} ; D y_{6} x_{1}=0,243 ; F_{p}=3,2
\end{gathered}
$$

Thus, the change in the volumes of sold innovative products which are new to the Ukrainian market is determined by a third of the previous-year costs of internal research and the purchase of machinery, equipment and software.

The dependence of the volume of sold innovative products outside Ukraine $\left(Y_{6}, Y_{7}\right)$ on the basis of regression models shows that there is a close link with the total costs of innovation $\left(x_{1}\right)$, which were made in the previous period, that is, with a one-year lag (22):

$$
\begin{gathered}
Y_{6} x_{1}=152,2+0,186 x_{1}-0,0000014 x_{1}{ }^{2} ; \\
Y_{6} x_{1}=152,2+0,186 x_{1}-0,0000014 x_{1}{ }^{2} ; \\
D y_{6} x_{1}=0,932 ; F_{p}=53,8 ; F_{\alpha}\{\alpha=0,05 ; v 1=2 ; v 2=9\}=4,26
\end{gathered}
$$

A differential analysis of the impact of expenditures on separate areas of innovation indicates virtually no link between the volume of SIP outside Ukraine and the costs of domestic research $\left(x_{2}\right)$ - equations (23), (24), (25), (26) - where the link density is very low. This indicates the lack of knowledge and skills at enterprises to implement research and development on their 
own at the required level, sufficient to produce innovation and products competitive in the foreign markets.

$$
\begin{gathered}
Y_{6} x_{2}=662,43-2043,7 \frac{1}{x_{2}} D y_{6} x_{2}=0,047 ; F_{p}=0,5 \\
Y_{6} x_{2}=662,43-2043,7 \frac{1}{x_{2}} D y_{6} x_{2}=0,047 ; F_{p}=0,5 \\
Y_{6} x_{2}=e^{4,6} x_{2}^{1,162} ; D y_{6} x_{2}=0,032 ; F_{p}=0,33 \\
Y_{6} x_{2}=e^{4,6} x_{2}^{1,162} ; D y_{6} x_{2}=0,032 ; F_{p}=0,33 \\
Y_{6} x_{2}=574,42-1204,6 \frac{1}{x_{2}} D y_{6} x_{2}=0,081 ; F_{p}=0,885 \\
Y_{6} x_{2}=574,42-1204,6 \frac{1}{x_{2}} D y_{6} x_{2}=0,081 ; F_{p}=0,885 \\
Y_{6} x_{2}=e^{4,316} x_{2}{ }^{1,264} ; D y_{6} x_{2}=0,121 ; F_{p}=1,4 \\
Y_{6} x_{2}=e^{4,316} x_{2}^{1,264} ; D y_{6} x_{2}=0,121 ; F_{p}=1,4
\end{gathered}
$$

Expenditures on purchasing the machinery, equipment and software have a greater impact on the change in sales outside Ukraine, even coefficients of determination for all versions of the statement show that an increase of this type of costs by $25 \%-28 \%$ determines the change in sales. However, the expenditures of the previous year have a more significant impact on the parameters of power regression (see equation (27)). Each increase of percentage in expenditures in this area causes an increase in SIP outside Ukraine by $0.533 \%$. Expenditures on external R\&D $\left(x_{3}\right)$ have even more significant impact on the dynamics of this indicator, taking into account the one-year lag - equation (28). Thus, the change in the volume of SIP outside Ukraine by $77.5 \%$ is due to the costs of external research, which were made in the previous year.

$$
\begin{gathered}
Y_{6} x_{4}=e^{42,284} x_{4}{ }^{0,533} D y_{6} x_{4}=0,409 ; \\
Y_{6} x_{4}=e^{42,284} x_{4}{ }^{0,533} D y_{6} x_{4}=0,409 ; \\
F_{p}=6,92 ; F_{\alpha}\{\alpha=0,05 ; v 1=2 ; v 2=10\}=4,96 ; \\
Y_{6} x_{3}=278,23-14,4 x_{3}+0,212 x_{3}{ }^{2} ; \\
Y_{6} x_{3}=278,23-14,4 x_{3}+0,212 x_{3}{ }^{2} ; \\
D y_{6} x_{3}=0,775 ; F_{p}=15,54 ; F_{\alpha}\{\alpha=0,05 ; v 1=2 ; v 2=9\}=4,26 ;
\end{gathered}
$$

The results of the study showed a significant link between investment in innovation and the production of innovative products. It is revealed that, on average, the change in the volumes of sold innovative products by $60.0 \%-70.0 \%$ is due to the change in the total costs of innovation activities. A correlation-regression analysis also revealed a different impact of the 
components of innovations costs on the volume and structure of sold innovative products, which confirms the hypothesis. The total amount of SIP largely depends on the level of costs to purchase machinery, equipment and software. Each percentage of costs in this area is accompanied by an increase in SIP by $0.701 \%$, as well as costs related to the component "Other". The growth of the costs by $1 \%$ leads to an increase in the volume of SIP by $0.55 \%$. The positive dynamics of sold innovative products new to the market is mainly determined by the costs of internal research, machinery and equipment, as well as other costs. All together, these three factors cause changes in sales of almost $50 \%$, but standardized ratios show twice as much impact of costs on domestic R\&D than other areas of expenditure. Volumes of sold innovative products outside Ukraine are largely determined by the volume of expenditures on external research. Calculations have shown that the change in the volume of SIP outside Ukraine by $77.5 \%$ is due to the costs of external research, which incurred in the previous year. Thus, influencing the structure of innovation costs, a company can achieve maximum economic return from them and significantly increase the level of its competitiveness.

\section{Conclusions}

The results of the analysis confirmed the research hypothesis on the existence of the dependence of the total volume of sold innovative industrial products and its share that is new to the market, as well as the volume of products sold outside Ukraine, on different types of innovation costs. These results are consistent with the conclusions of most Ukrainian and foreign scientists on the existence of a close positive relationship between investment in innovations and company performance.

The study showed that, in general, the total costs of innovation is quite closely related to the amount of SIP both in the respective years and taking into account the one- and two-year lag of costs. It is determined that approximately $70 \%$ of the change in the volume of SIP is due to the direct dynamics of the total costs of innovation. Among the components of costs in the areas of innovation, the greatest impact, both in separate years and the lags, is observed in the costs of purchasing machinery, equipment and software. There is a high-density link between the volume of SIP and the costs in the direction of "Other".

The change in the volume of sold innovative products new to the market is only one third due to the impact of total expenditures on innovation in the current year. Expenditures for the previous year have a more significant impact. Each percentage of their growth causes an increase in sales in this area by $0.65 \%$. Expenditures on external $R \& D$, which were invested in the previous year, have the greatest impact on the change in the volume of new products sold in the market. The volume of SIP outside Ukraine mainly depends on the volume of total expenditures on innovation for the previous year. Each percentage of expenditures is accompanied by an increase in the volume of sold innovative products outside Ukraine in the following year by $0.62 \%$. Expenditures on external R\&D in the previous year have the most significant impact on the volume of SIP outside Ukraine. 
Within the framework of further research, the development of proposals for optimizing the structure of innovation costs in the industry of Ukraine, taking into account the results of the evaluation, seems relevant.

\section{References}

Alymov, O. M. et al. (2014). Pershyy etap modernizatsiyi ekonomiky Ukrayiny: dosvid ta problemy The [First Stage of Modernization of the Ukrainian Economy: Experience and Problems]. Zaporizhia: Classical Private University. [in Ukrainian].

Amosha, O. et al. (2019). Industriya 4.0: napryamky zaluchennya investytsiy z urakhuvannyam interesiv vitchyznyanykh vyrobnykiv [Industry 4.0: The Directions for Attracting Investment from the Perspective of the Interests of Domestic Producers]. Economic Herald of the Donbass, 3(57), 189216. https://doi.org/10.12958/1817-3772-2019-3(57)-189-216

Amosha, O. I. et al. (2018). Modernizatsiya ekonomiky promyslovykh rehioniv Ukrayiny $v$ umovakh detsentralizatsiyi upravlinnya [Economic Modernization of Industrial Regions of Ukraine in a Decentralized Environment]. Kyiv: Institute of Industrial Economics of the National Academy of Sciences of Ukraine. [in Ukrainian].

Boiko, V., Kwilinski, A., Misiuk, M., \& Boiko, L. (2019). Competitive Advantages of Wholesale Markets of Agricultural Products as a Type of Entrepreneurial Activity: The Experience of Ukraine and Poland. Economic Annals-XXI, 175(1-2), 68-72. https://doi.org/10.21003/ea.V175-12

Carvalho, L., \& Avellar, A.P. (2016). Innovation and Productivity: Empirical Evidence for Brazilian Industrial Enterprises. Revista de Administração, 52(2), 1-15. https://doi.org/10.1016/j.rausp.2016.12.009

Ciocanel, A. B., \& Pavelescu, F. M. (2015). Innovation and Competitiveness in European Context. Procedia Economics and Finance, 32, 728-737. https://doi.org/10.1016/S2212-5671(15)01455-0

Czyżewski, B., Matuszczak, A., \& Miśkiewicz, R. (2019). Public goods versus the farm price-cost squeeze: shaping the sustainability of the EU's common agricultural policy. Technological and Economic Development of Economy, 25(1), 82-102. https://doi.org/10.3846/tede.2019.7449

Dementyev, V.V., \& Kwilinski, A. (2020). Institutsionalnaya sostavlyayuschaya izderzhek proizvodstva [Institutional Component of Production Costs]. Journal of Institutional Studies, 12(1), 100-116. https://doi.org/10.17835/2076-6297.2020.12.1.100-116

Dzwigol, H. (2020a). Innovation in Marketing Research: Quantitative and Qualitative Analysis. Marketing and Management of Innovations, 1, 128-135. http://doi.org/10.21272/mmi.2020.1-10

Dzwigol, H. (2020b). Methodological and Empirical Platform of Triangulation in Strategic Management. Academy of Strategic Management Journal, 19(4), 1-8.

Dzwigol, H., Dzwigol-Barosz, M., Miskiewicz, R., \& Kwilinski, A. (2020a). Manager Competency Assessment Model in the Conditions of Industry 4.0. Entrepreneurship and Sustainability Issues, 7(4), 2630-2644. https://doi.org/10.9770/jesi.2020.7.4(5)

Dzwigol, H., Dzwigol-Barosz, M., \& Kwilinski, A. (2020b). Formation of Global Competitive Enterprise Environment Based on Industry 4.0 Concept. International Journal of Entrepreneurship, 24(1), 1-5. 
Dźwigoł, H., \& Wolniak, R. (2018). Controlling w procesie zarządzania chemicznym przedsiębiorstwem produkcyjnym [Controlling in the management process of a chemical industry production company]. Przemys/ Chemiczny, 97(7), 1114-1116. https://doi.org/10.15199/62.2018.7.15

Dzwigoł, H., Dzwigoł-Barosz, M., Zhyvko, Z., Miskiewicz, R., \& Pushak, H. (2019a). Evaluation of the Energy Security as a Component of National Security of the Country. Journal of Security and Sustainability Issues, 8(3), 307-317. http://doi.org/10.9770/jssi.2019.8.3(2)

Dzwigol, H., Aleinikova, O., Umanska, Y., Shmygol, N., \& Pushak, Y. (2019b). An Entrepreneurship Model for Assessing the Investment Attractiveness of Regions. Journal of Entrepreneurship Education, 22, (SI1), 1-7.

Dźwigoł, H., Shcherbak, S., Semikina, M., Vinichenko, O., \& Vasiuta, V. (2019c). Formation of Strategic Change Management System at an Enterprise. Academy of Strategic Management Journal, 18(SI1), 1-8. Retrieved from https://www.abacademies.org/articles/Formation-of-strategic-changemanagement-system-at-enterprise-1939-6104-18-SI-1-454.pdf

Furmaniak, S., Gauden, P.A., Patrykiejew, A., Miśkiewicz, R., \& Kowalczyk, P. (2018). Carbon Nanohorns as Reaction Nanochambers - a Systematic Monte Carlo Study. Scientific Reports, 15407. https://doi.org/10.1038/s41598-018-33725-z

Furmaniak, S., Gauden, P.A., Patrykiejew, A., Miśkiewicz, R., \& Kowalczyk, P. (2019a). The effects of confinement in pores built of folded graphene sheets on the equilibrium of nitrogen monoxide dimerization reaction. Journal of Physics Condensed Matter, 31(13), 135001, 1-12. https://doi.org/10.1088/1361-648X/aaffb3

Furmaniak, S., Gauden, P.A., Patrykiejew, A., Szymański, G., Miśkiewicz, R., \& Kowalczyk, P. (2019b). In silico study on the effects of carbonyl groups on chemical equilibrium of reactions with a polar product occurring under confinement in pores of activated carbons. Chemical Engineering Communications, 1-12. https://doi.org/10.1080/00986445.2019.1700115

Golovatyuk, V. M., Pidorycheva, I. Yu., \& Soloviov, V. P. (2018). Stratehichni ryzyky naukoyemnoho rozvytku natsional'noyi ekonomiky [Strategic Risks for Knowledge-Based Evolution of the National Economy]. Science and Science of Science, 3(101),3-23. https://doi.org/10.15407/sofs2018.03.003 [in Ukrainian].

Haltiwanger, J., Jarmin, R., \& Schank, T. (2003). Productivity Investment in ICT and Market Experimentation: Micro Evidence from Germany and the United States. Washington, DC: Center for Economic Studies Working Paper CES-03-06, US Bureau of the Census.

Jamel, L. et al. (2020). The Nexus between Education and Economic Growth: Analyzing Empirically a Case of Middle-Income Countries. Virtual Economics,3(2), 43-60. https://doi.org/10.34021/ve.2020.03.02(3)

Kuzior, A., Kwilinski, A., \& Tkachenko, V. (2019). Sustainable Development of Organizations Based on the Combinatorial Model of Artificial Intelligence. Entrepreneurship and Sustainability, 7(2), 13531376. http://doi.org/10.9770/jesi.2019.7.2(39)

Kuzior, A., \& Kuzior, P. (2020). The Quadruple Helix Model as a Smart City Design Principle. Virtual Economics, 3(1), 39-57. https://doi.org/10.34021/ve.2020.03.01(2)

Kwilinski, A. (2019). Implementation of Blockchain Technology in Accounting Sphere. Academy of Accounting and Financial Studies Journal, 23(SI2), 1528-2635-23-SI-2-412: 1-6. 
Kwilinski, A., Tkachenko, V., \& Kuzior, A. (2019a). Transparent Cognitive Technologies to Ensure Sustainable Society Development. Journal of Security and Sustainability Issues, 9(2), 561-570 http://doi.org/10.9770/jssi.2019.9.2(15)

Kwilinski, A., Dalevska, N., Kravchenko, S., Hroznyi, I., \& Kovalenko, I. (2019b). Formation of the Entrepreneurship Model of E-Business in the Context of the Introduction of Information and Communication Technologies. Journal of Entrepreneurship Education, 22(SI1), 1528-2651-22-S1337: 1-7.

Kwilinski, A., Ruzhytskyi, I., Patlachuk, V., Patlachuk, O., \& Kaminska, B. (2019c). Environmental Taxes as a Condition of Business Responsibility in the Conditions of Sustainable Development. Journal of Legal, Ethical and Regulatory Issues, 22(SI2) 1544-0044-22-SI-2-354: 1-6.

Kwilinski, A., Volynets, R., Berdnik, I., Holovko, M., \& Berzin, P. (2019d). E-Commerce: Concept and Legal Regulation in Modern Economic Conditions. Journal of Legal, Ethical and Regulatory Issues, 22(SI2), 1544-0044-22-SI-2-357: 1-6.

Kwilinski, A., Zaloznova, Y., Trushkina, N., \& Rynkevych, N. (2020a). Organizational and Methodological Support for Ukrainian Coal Enterprises Marketing Activity Improvement. E3S Web of Conferences, 168, 00031. https://doi.org/10.1051/e3sconf/202016800031

Kwilinski, A., \& Kuzior, A. (2020). Cognitive Technologies in the Management and Formation of Directions of the Priority Development of Industrial Enterprises. Management Systems in Production Engineering, 28(2), 133-138. https://doi.org/10.2478/mspe-2020-0020

Kwilinski, A., Slatvitskaya, I., Dugar, T., Khodakivska, L., \& Derevyanko, B. (2020b). Main Effects of Mergers and Acquisitions in International Enterprise Activities. International Journal of Entrepreneurship, 24(Special Issue: Entrepreneurship, Innovation Management and Sustainability), 1-8.

Kwilinski, A., Dzwigol, H., \& Dementyev, V. (2020c). Model of Entrepreneurship Financial Activity of the Transnational Company Based on Intellectual Technology. International Journal of Entrepreneurship, 24(Special Issue: Entrepreneurship, Innovation Management and Sustainability), 1-5.

Kwilinski, A., Litvin, V., Kamchatova, E., Polusmiak, J., \& Mironova, D. (2020d). Information Support of the Entrepreneurship Model Complex with the Application of Cloud Technologies. Journal of Entrepreneurship Education, 23(SI1), 1-9.

Kwilinski, A., Vyshnevskyi, O., \& Dzwigol, H. (2020e). Digitalization of the EU Economies and People at Risk of Poverty or Social Exclusion. Journal of Risk and Financial Management, 13(7), 142. https://doi.org/10.3390/jrfm13070142

Miśkiewicz, R. (2018). The Importance of Knowledge Transfer on the Energy Market. Polityka Energetyczna, 21(2), 49-62. http://dx.doi.org/10.24425\%2F122774

Miśkiewicz, R, \& Wolniak, R. (2020). Practical Application of the Industry 4.0 Concept in a Steel Company. Sustainability, 12(14), 5776. https://doi.org/10.3390/su12145776

Morris, D. M. (2018). Innovation and Productivity among Heterogeneous Firms. Research Policy, 47(10),1918-1932. https://doi.org/10.1016/j.respol.2018.07.003

Pająk, K., Kamińska, B., \& Kvilinskyi, O. (2016). Modern Trends of Financial Sector Development under the Virtual Regionalization Conditions. Financial and Credit Activity: Problems of Theory and Practice, 2(21), 204-217. https://doi.org/10.18371/fcaptp.v2i21.91052 
Pająk, K., Kvilinskyi, O., Fasiecka, O., \& Miśkiewicz, R. (2017). Energy Security in Regional Policy in Wielkopolska Region of Poland. Economics and Environment, 2(61), 122-138. Retrieved from https://www.ekonomiaisrodowisko.pl/uploads/eis\%2061/11_pajak.pdf

Ramadani, V. et al. (2019). Product Innovation and Firm Performance in Transition Economies: A MultiStage Estimation Approach. Technological Forecasting and Social Change, 140, 271-280. https://doi.org/10.1016/j.techfore.2018.12.010

Savchenko, T., Basiurkina, N., Rodina, O., \& Kwilinski, A. (2019). Improvement of the assessment methods of product competitiveness of the specialized poultry enterprises. Management Theory and Studies for Rural Business and Infrastructure Development, 41(1), 43-61. https://doi.org/10.15544/mts.2019.05

Soldak, M. O., \& Shamileva, L. L. (2018). Factors of the Industrial Regions' Development: Opportunities for Modernization on an Innovative Basis. Economy of industry, 1(81), 21-43. https://doi.org/10.15407/econindustry2018.01.021

State Statistics Service of Ukraine. (2018). Scientific and Innovatory Work in Ukraine. Kyiv: State Statistics Service of Ukraine.. Retrieved from http://www.ukrstat.gov.ua/druk/publicat/kat_u/ 2018/zb/09/zb_nauka_2017.pdf [in Ukrainian].

Tkachenko, V., Kwilinski, A., Klymchuk, M., \& Tkachenko, I. (2019a). The Economic-Mathematical Development of Buildings Construction Model Optimization on the Basis of Digital Economy. Management Systems in Production Engineering, 27(2), 119-123. http://doi.org/10.1515/mspe2019-0020

Tkachenko, V., Kwilinski, A., Korystin, O., Svyrydiuk, N., \& Tkachenko, I. (2019b). Assessment of Information Technologies Influence on Financial Security of Economy. Journal of Security and Sustainability, 8(3), 375-385. http://doi.org/10.9770/jssi.2019.8.3(7)

Tkachenko, V., Kuzior, A., \& Kwilinski, A. (2019c). Introduction of Artificial Intelligence Tools into the Training Methods of Entrepreneurship Activities. Journal of Entrepreneurship Education, 22(6), 110.

Tkachenko, V., Kwilinski, A., Tkachenko, I., \& Puzyrova, P. (2019d). Theoretical and Methodical Approaches to the Definition of Marketing Risks Management Concept at Industrial Enterprises. Marketing and Management of Innovations, 2, 228-238. http://doi.org/10.21272/mmi.2019.2-20 